\title{
Tackling the Pandemic COVID-19: the Bangladesh Perspective
}

\author{
Running article: Tackling COVID-19 by Bangladesh
}

Md. Taimur Islam ${ }^{1}$, Anup Kumar Talukder ${ }^{2}$, Md. Nurealam Siddiqui ${ }^{3}$, and Tofazzal $\operatorname{Islam}^{4} *$

${ }^{1}$ Department of Pathobiology, Faculty of Veterinary Medicine and Animal Science, Bangabandhu Sheikh Mujibur Rahman Agricultural University, Gazipur 1706, Bangladesh

${ }^{2}$ Department of Gynecology, Obstetrics \& Reproductive Health, Faculty of Veterinary Medicine and Animal Science, Bangabandhu Sheikh Mujibur Rahman Agricultural University, Gazipur 1706, Bangladesh

${ }^{3}$ Department of Biochemistry and Molecular Biology, Bangabandhu Sheikh Mujibur Rahman Agricultural University, Gazipur 1706, Bangladesh

${ }^{4}$ Institute of Biotechnology and Genetic Engineering, Bangabandhu Sheikh Mujibur Rahman Agricultural University, Gazipur 1706, Bangladesh

Corresponding authors:

Professors Md. Tofazzal Islam

E-mails: tofazzalislam@yahoo.com 


\section{ABSTRACT}

An outbreak of a pandemic COVID-19 disease caused by a novel coronavirus SARS-CoV-2 has posed a serious threat to human health and the economy of the whole world. Bangladesh is one of the most densely populated countries in the world, which has also come under the attack of this viral disease. This perspective report aimed to describe the responses of Bangladesh to tackle the COVID-19, particularly on how Bangladesh is dealing with this novel viral disease with limited resources. The first case of a COVID-19 patient was detected in Bangladesh on March 8, 2020. Since then, a total of 2,144 peoples are officially reported as COVID-19 infected with 84 deaths. To combat the COVID-19, the government has taken various steps to tackle the epidemic outbreak of it such as diagnosis of the suspected cases, quarantine of doubted people and isolation of infected patients, local or regional lockdown, grant general leave from all offices for staying home of people, increase public awareness and enforce social distancing and so on. In addition, to address the socio-economic situations, the government announced several financial stimulus packages of about USD 11.17 billion. However, very limited diagnostic facilities, health workers, resources such as hospital beds, personal protective equipment, intensive care unit, and ventilators in the hospitals along with limited public unawareness are the major challenges for Bangladesh to tackle the situation effectively. This report described the responses of Bangladesh to tackle the COVID-19 and discusses prevailing challenges to mitigate this highly contagious disease with limited resources.

Keywords: SARS-CoV-2, COVID-19, Bangladesh, Pandemic, stimulus package

\section{INTRODUCTION}

A cluster of patients of pneumonia with unknown etiology was first reported in the Wuhan city of Hubei Province in China in December 2019 (1-3). The initial symptoms were 
fever, cough, dyspnea, myalgia or fatigue, headache, hemoptysis, diarrhea and acute respiratory distress syndrome (ARDS) (4). The Wuhan is the most populated city in central China with a population of over 11 million $(5,6)$. After a few days, Chinese health authorities confirmed that those cases were associated with a novel CoV (3). Eventually, the Chinese Centre for Disease Control and Prevention (CCDC) has identified the causative agent from throat swab samples on January 7, 2020, and named the pathogen as Severe Acute Respiratory Syndrome Coronavirus-2 (SARS-CoV-2). On the other side, the World Health Organization (WHO) named this disease as a coronavirus disease-19 (COVID-19) (6). The WHO has declared this ongoing outbreak of COVID-19 as a Public Health Emergency of International Concern on January 30, 2020. According to WHO, the countries with vulnerable health systems are at higher risk. As of April 18, 2020, the disease has infected at least $2,261,425$ people and has resulted in at least 154,734 deaths globally.

The emergency committee of WHO has announced that the spread of COVID-19 could be discontinued by trace, early detection, isolation, prompt treatment (6). To date, more than 213 countries or territories have confirmed the occurrence of COVID-19 including Bangladesh (7). Bangladesh is one of the most vulnerable countries due to high population density (170 million people in 147,000 sq.km), poor health care systems and the weak economy. In recent years, Bangladesh's economy has been growing well with a GDP growth rate of more than $7.5 \%$, however, $20 \%$ of the population is poor. Nevertheless, because of the rapid spread of the COVID-19, Bangladesh's economy has already started taking a big hit. The nationwide shutdown has already suspended almost all economic activities except agriculture and made thousands of employments at risk. International trade orders, especially in ready-made garments industries, are being greatly canceled. While the richest, developed and the most powerful countries of the world have been struggling to fight against the COVID-19, failing to provide the necessary support and medical treatment to their patients. It is a now worrying question how is Bangladesh responding and tackling the pandemic 
COVID-19 with its relatively poor health management system. Several opinion papers have been published in different countries regarding the outbreak of COVID-19 $(8,9)$. The present report aimed to focus our understanding of the biology of this novel $\mathrm{CoV}$ and describes how a resource-poor country Bangladesh is tackling this fearsome disease by adopting steps and stimulus packages.

\section{RESPONSES OF BANGLADESH TO TACKLE COVID-19}

On March 8, 2020, three cases of pandemic COVID-19 were confirmed by the Institute of Epidemiology, Disease Control and Research (IEDCR) for the first time in Bangladesh (7). Till April 5, the number of positive cases was only 88 whereas, on April 16, the number became 2,144 with 84 deaths (10). This is because the number of tests has been increased these days which is still not in sufficient number. The lower number of positive cases and deaths might be attributed to the lower test of samples in comparison to other countries.

The government of Bangladesh has taken many major steps such as i) the formation of a national COVID-19 response committee, headed by the Minister for Health; ii) cancellation of the grand inauguration ceremony of the father of the Nation Bangabandhu Sheikh Mujibur Rahman's birth centenary celebration programs; iii) closure of all government and private offices; iv) ban of all public transport; v) suspension of all domestic and international flights; vi) deployment of the armed forces, including police and army to ensure that people maintain social distancing; vii)The government is operating the 'Rice for TK 10 per KG (approx. 12 cents/kg rice)' program for the needy people throughout the country.

Moreover, the government has declared several stimulus packages for the business industry and ensuring the food security of the country (Table 1). These declarations include: (i) Stimulus packages of the total amount of approximately USD 8.5 billion for the big industries, small and medium enterprises, including cottage industries, social safety. This 
package is based on four main features: a) increase public expenditure; b) introduce fiscal packages; c) expand social security programs; and d) increase money supply. (ii) The stimulus package of the total amount of approximately USD 589 million to pump running capital into the agricultural sector to ensure food security. Besides, previously the government has allocated approximately USD 589 million to give subsidy to farmers aiming to increase agricultural production and to maintain national food and nutritional security. Major steps taken by the government of Bangladesh to tackle the COVID-19 are described briefly in Table 1.

\section{MAJOR CHANLLENGES OF COVID-19 IN BANGLADESH}

Though the government has taken some essential steps, such as restrictions on air and land travel, increasing public awareness, quarantine of the people who have returned to the country and other suspected people, promotion of self-isolation, social distancing, the lockdown of some areas, and the deployment of the law enforcement agencies and the army to motivate the people, and also a declaration of some stimulus packages for boosting the economy, many challenges are still remained to be addressed to effectively tackle this fearsome disease. The major challenges of addressing the COVID-19 in Bangladesh are briefly described as follows.

A limited number of test: As there is no effective treatment against COVID-19, this is very important to follow test, trace and treatment policies to tackle this highly contagious disease. It is crucial to diagnose the disease at the earliest stage so that immediate tracing, isolation of the patient and quarantine of the person(s), who have the possibility to come in contact with the patient, could be ensured. Less than two thousand daily test capacity is very low in a country of 170 million of population. Until April 16, Bangladesh has tested 21,307 samples whereas Germany has tested $1,728,357$ samples. Thus, it is believed that most of the people having COVID-19 were left undetected due to the lower number of tests. But after 
increasing the number of tests, the number of positive cases is growing high very rapidly in Bangladesh. An extremely limited number of tests is increasing the chances of leaving a higher number of COVID-19 cases undetected in Bangladesh. It is highly recommended to increase the number of tests for suspected and asymptomatic people as soon as possible. Besides this, all identified and suspected cases must be quarantined and treatment should be provided if needed. The government must need to include all research institutes, universities, and other organizations that have the laboratory facility to increase the number of tests for diagnosing COVID-19. Convenient and rapid test methods should be urgently introduced.

Lack of safety equipment: There is inadequate supply of PPE, masks, hand gloves to the health service providers, which is one of the major constraints in providing treatment facilities. A significant lack of safety equipment is fuelling the concern for frontline health service providers like doctors and nurses. Collectively, the limitation of PPE and inadequate test facilities of real-time RT-PCR are the big challenges for Bangladesh. The government has to make available and import these protective gears immediately.

Lack of skilled human resources: The use of real-time RT-PCR-based-assay to diagnose COVID-19 requires skilled human resources and sophisticated laboratory facilities. To avoid contamination, false-negative results and risks of biological hazards, the government is not allowing all hospitals, and organizations to perform the test. No rapid test protocol has yet to be used in Bangladesh for diagnosing the COVID-19. Bangladesh needs to introduce rapid protein/antibody-based rapid test protocols to satisfy the skyrocketing demand for diagnosis of COVID-19 for tackling this socially spread fatal disease.

Limited treatment facilities: The diagnosis and treatment facilities of COVID-19 in Bangladesh are very limited. Bangladesh has eight hospital beds per 10,000 people, whereas the USA has 29 beds per 10,000 people and China has 42. Moreover, the government health department of Bangladesh has only 432 ICU beds in total, only 110 of which are placed outside the capital city, Dhaka. The private healthcare sector has additional 737 ICU beds and 
this is for a population of 170 million. The government has to prepare special hospitals as soon as possible with a sufficient number of ICU beds. Some private organizations may step forward to help the country during this critical situation.

In addition to the above-mentioned challenges, the country does not have enough ventilator machines to provide respiratory support to critical COVID-19 patients. Right now, only 1,769 ventilators are available in Bangladesh that means an average of one ventilator available for every 93,273 persons. Also, most of the intensive care beds and ventilators of the country are installed at hospitals in major cities, mostly in Dhaka, which means that people from remote areas will not be able to get it when they will fall in critical condition. Along with the government, other industrialists have to come forward to arrange ICU beds, mechanical ventilators and to import these instruments at the earliest period of time. The government should declare this importation as tax-free.

Limited number of health service provider: Another big problem is fewer doctors and nurses in comparison to other countries. Bangladesh has 0.5 doctors on average per 1,000 people, whereas in Italy has 4.1 doctors. Moreover, many hospitals especially some doctors, nurses and other health officials were showing unwillingness to provide treatment for COVID-19 patients that is really unethical and unprofessionalism from hospital authorities and doctors as well. They are scared of getting infected as they don't have sufficient protective equipment. In this situation of secondary and tertiary steps, if any major outbreak will occur, it could lead to a huge disaster in the country. However, the government has declared incentives and health insurance for the doctor, nurses who will provide support to fight against COVID-19. Besides the government has to arrange quick training for community health workers who can provide support in remote areas.

Community transmission: At this stage of disease course in Bangladesh, community transmission is occurring, which is very scary. Many positive cases have been reported already where the infected person neither came from abroad nor any family members have 
returned from abroad, which suggests that community transmission has taken place. To date, people from 49 districts (out of 64 districts) have been infected with COVID-19 (Figure 1). The number if new infected patients and deaths are increasing geometrically. Print, electronic and social media published a series of the report about suspicious deaths of patients with COVID-19 symptoms. Some of the death cases were recorded at COVID-19 isolation centers at hospitals at the district level. In due courses, others were denied for providing treatment, even though no tests were performed to confirm contagion. Samples test facilities for COVID-19 were centralized to only IEDCR in the capital Dhaka for a long time, although patients with suspicious symptoms of COVID-19 were reported throughout the country. However, the government is now extending the test facilities for COVID-19 at divisional level, mainly based on the divisional government medical colleges in Bangladesh. Obviously, the number of the test must be extended across the country. In addition to this, at the earliest possible time, test facilities should be made available in different areas of the country and all suspected cases need to be tested immediately.

Large number of vulnerable and disadvantaged people: Special attention also has to be paid to protect the vulnerable groups or individuals such as the elder people and the disadvantaged, including day-laborers, patients with comorbidities who have a higher risk of getting infected. The elder people are more susceptible because of their low immunity to fight against the disease and therefore, they need more intensive care-based treatment which would require an increased number of ventilators. Some disadvantaged groups, day-laborers are also vulnerable and may cause mass transmission as they need to go outside to earn their daily food items. Again, working-aged people need to go outside to work for maintaining their daily life, which might contribute to getting the infection in those people. Through providing essential support such as daily needs, food, relief to the disadvantaged people at this crucial time may reduce their sufferings and also reduce their chance of getting infected and infecting 
others. At this point, the government has to monitor this program very strictly otherwise there is a chance of misuse of this relief item by immoral local leaders.

Lack of public awareness: To maintain social distancing is a very difficult task in a highly populated country like Bangladesh. Many people are not so much conscious about the fatal effect of COVID-19. Young people may be a little bit careless regarding COVID-19. Along with the government's step, every person should try himself to keep distancing with others, washing hands, not to go outside without any important reason.

Large number of Rohingya refugees: Another big challenge is to save more than one million Rohingya refugees from rapidly spreading COVID-19, living in the confined conditions in Cox's Bazar district of Bangladesh. The number of ventilators in Cox's Bazar is very limited, where around 3.3 million people live. If severe community transfer will happen, many lives will be lost. The number of tests, ventilators and special attention regarding this issue have to be increased at the earliest period of time.

Effects on economy of the country: More importantly, the present outbreak of COVID-19 will seriously affect the economy of the country in various ways that include mainly disruption in textile and garments manufacturing industries, trades and business of deferent sectors, tourism, in agricultural production, and unemployment of a huge number of people, etc. The government has already declared some stimulus packages for the industrial sector to provide financial support and to boost up the threatened economy.

Effects on agricultural sector: Bangladesh is an agrarian country. Currently, local boro rice harvesting season is going on in Bangladesh especially in low lying areas (haor in Bangla). Also, the haor area is a big source of rice crops in the country. But due to the outbreak of COVID-19, there is a possible chance of shortage of laborers in the haor area. This will also be a big disaster for the country. To address this situation, the government arranged a good number of the harvester and other facilities to harvest the boro rice before the flash flood inundate the areas. After the outbreak of COVID-19 in Bangladesh, some people 
started to disseminate false propaganda that coronavirus causing COVID-19 in humans may transmit from the livestock and poultry and their products (meat, milk, and egg). Rather, this meat, milk, and egg are essential to humans for boosting up their immunity which might play pivotal roles in fighting against COVID-19. Thus, this kind of harmful activity, through disseminating false propaganda through social networks such as Facebook, has already made a negative impact on the poultry and livestock industry of the country. The price of milk, meat, and eggs has been decreased drastically. It should be noted that approximately $20 \%$ of the people of Bangladesh directly or indirectly rely on the livestock and poultry sector for their livelihoods. In this regard, the Government has to increase public awareness through television, social media, print, and electronic media to eat more meat, fish, and eggs for becoming healthy which is very important to increase body immunity. However, the government has announced a new stimulus package of approximately USD 589 million to provide financial support only to the farmers. Also, the government has declared to arrange health checkups, sanitary equipment, vehicles for transportation, resident for the farmers who are willing to go to haor area from harvesting of the boro crop.

The overall current situation of the health service system of Bangladesh has illustrated above, which clearly reflects the worsening situation of Bangladesh to tackle the fatal COVID-19 epidemic in the country.

\section{CONCLUSION}

The COVID-19 has been a serious problem already for Bangladesh in the last few weeks after its emergence on 8th March in the country. Essentially, the government has taken many timely initiatives such as diagnosis of suspected cases, quarantine of doubted people and isolation of infected patients, local or regional lockdown, increasing public awareness and social distancing with the announcement of many financial benefits for industries, agricultural production, and daily workers. However, testing the limited number of samples, scarcity of 
diagnostic kits and insufficient PPE, ICU, and ventilators in the hospitals along with public unawareness are the major challenges for combating the situation. Therefore, the government should take the necessary actions to bring the COVID-19 detecting device from abroad. At the same time, the government also needs to import PPE, face masks, ventilators, and ICU beds on an urgent basis to fight against lethal COVID-19. Some local industries are currently planning to manufacture life-saving ventilators that might be helpful in the coming days. The government should order mandatory lockdown in vulnerable places. It would be an impossible task for the government to fight against the threat alone without the required cooperation from the society and private sectors. In fact, government, non-government, autonomous organizations, private organizations, individual philanthropists, industrialists, celebrities, sportsmen, volunteers, and ordinary people should work unitedly to fight against the fearsome COVID-19. In addition, the government needs to allocate sufficient research funds to conduct research on COVID-19. Furthermore, it is needed to circulate the news and instruction continuously regarding COVID-19 to increase public awareness. Along with the government, people also must need to maintain social distancing, personal awareness, personal hygiene, self-quarantine condition and to obey the rules of the country and WHO as well.

\section{CONFLICT OF INTEREST STATEMENT}

The authors declare that the research was conducted in the absence of any commercial or financial relationships that could be construed as a potential conflict of interest.

\section{AUTHOR CONTRIBUTIONS}

MTI: Conceived, collected all information and wrote the main manuscript; AKT: Analyzed data and edited the manuscript; MNS: Analyzed data; TI: Conceived idea, coordinated, critically edited and revised the manuscript. 


\section{REFERENCES}

1. Zhu N, Zhang D, Wang W, Li X, Yang B, Song J, et al. A novel coronavirus from patients with pneumonia in China, 2019. New Engl J Med (2020) 382: 727-733 doi:10.1056/NEJMoa2001017

2. Wang C, Horby PW, Hayden FG, and Gao GF. A novel coronavirus outbreak of global health concern. Lancet (2020) 395: 470-473. doi.:10.1016/S0140$6736(20) 30185-9$

3. Lu H, Stratton CW, and Tang YW. Outbreak of Pneumonia of Unknown Etiology in Wuhan China: the Mystery and the Miracle. J Med Virol (2020) 92: 401-402. doi:10.1002/jmv.25678

4. Huang C, Wang Y, Li X, Ren L, Zhao J, Hu Y. et al. Clinical features of patients infected with 2019 novel coronavirus in Wuhan, China. Lancet (2020) 395: 497-506. doi:10.1016/S0140-6736(20)30183-5

5. Chen N, Zhou M, Dong X, Qu J, Gong F, Han Y, et al.. Epidemiological and clinical characteristics of 99 cases of 2019 novel coronavirus pneumonia in Wuhan, China: a descriptive study. Lancet (2020) 395: 507-513. doi:10.1016/S0140-6736(20)30211-7

6. Sohrabi C, Alsafi Z, O’Neill N, Khan M, Kerwan A, Al-Jabir A. et al. World Health Organization declares global emergency: A review of the 2019 novel coronavirus (COVID-19). Inter J Surg (2020) 76: 71-76. doi:10.1016/j.ijsu.2020.02.034

7. Reuters. (2020). Bangladesh confirms its first three cases of coronavirus. https://www.reuters.com/article/us-health-coronavirus-bangladesh-idUSKBN20V0FS [Accessed March 8, 2020].

8. Anwar S, Nasrullah M, and Hossen MJ. COVID-19 and Bangladesh: challenges and how to address them. Front Pub Healt (2020). doi:10.3389/fpubh.2020.00154 
9. Lorenzo GD, and Rossella DT. Coronavirus disease (covid-19) in Italy: analysis of risk factors and proposed remedial measures. Front Med (2020) 7:140. doi:10.3389/fmed.2020.00140

10. Institute of Epidemiology, Disease Control and Research (IEDCR). (2020). Covid-19 Status Bangladesh. https://www.iedcr.gov.bd/ [Accessed April 12, 2020].

11. Institute of Epidemiology, Disease Control and Research (IEDCR). (2020). https://www.iedcr.gov.bd/website/images/files/nCoV/17th_april.jpg [Accessed April $18,2020]$.

Table 1. Major steps that were taken by the Government of Bangladesh to combat against COVID-19.

\begin{tabular}{|c|c|}
\hline Timeline & Major steps taken by the Government of Bangladesh \\
\hline $\begin{array}{l}\text { January 22, } \\
2020\end{array}$ & $\begin{array}{l}\text { The authorities of Hazrat Shahjalal International Airport in Dhaka, } \\
\text { Bangladesh started to screen all travelers coming from China by the thermal } \\
\text { scanners. }\end{array}$ \\
\hline $\begin{array}{l}\text { January } 31, \\
2020\end{array}$ & $\begin{array}{l}\text { Evacuated stranded Bangladeshi citizens from the Wuhan city of China } \\
\text { through a special flight of Biman Bangladesh Airlines and all of them were } \\
\text { quarantined for two weeks. }\end{array}$ \\
\hline $\begin{array}{l}\text { February 2, } \\
2020\end{array}$ & $\begin{array}{l}\text { The government of Bangladesh canceled on-arrival visas for Chinese } \\
\text { visitors. The Chittagong port took precautionary measures to stop the spread } \\
\text { of } \mathrm{CoV} \text { from the ships that bring goods from throughout the world. }\end{array}$ \\
\hline $\begin{array}{l}\text { March } \\
2020\end{array}$ & $\begin{array}{l}\text { Canceled the planned grand inauguration ceremony of the father of the } \\
\text { nation of Bangladesh Bangabandhu Sheikh Mujibur Rahman's birth } \\
\text { centenary celebration programs to avoid public gatherings, which was } \\
\text { scheduled to be held on March } 17 \text {. }\end{array}$ \\
\hline $\begin{array}{l}\text { March 16, } \\
2020\end{array}$ & $\begin{array}{l}\text { The Education Ministry of Bangladesh closed all educational institutions } \\
\text { until March 31, 2020, which is continuing. }\end{array}$ \\
\hline $\begin{array}{l}\text { March 18, } \\
2020\end{array}$ & $\begin{array}{l}\text { The government announced the National Preparedness and Response Plan } \\
\text { (NPRP) for COVID- } 19 \text {. }\end{array}$ \\
\hline
\end{tabular}




\begin{tabular}{|c|c|}
\hline $\begin{array}{l}\text { March 19, } \\
2020\end{array}$ & $\begin{array}{l}\text { The government declared the first lockdown at Shibchar of Madaripur } \\
\text { district. The government also ordered the local administrations to stop all } \\
\text { political and religious rallies, social and cultural gatherings. }\end{array}$ \\
\hline $\begin{array}{l}\text { March } \\
2020\end{array}$ & $\begin{array}{l}\text { The government announced to cancel all state public programs including the } \\
\text { celebration of 50th Independence Day and ordered not to gather to prevent } \\
\text { the spread of CoV. }\end{array}$ \\
\hline $\begin{array}{l}\text { March 22, } \\
2020\end{array}$ & $\begin{array}{l}\text { i) The Prime Minister of Bangladesh joined a video conference of the South } \\
\text { Asian Association for Regional Cooperation (SAARC) and played an } \\
\text { important role in generating a 'SAARC COVID-19 emergency fund' and } \\
\text { committed to contribute USD } 1.5 \text { million to combat novel pandemic } \\
\text { COVID-19 among SAARC regional countries. } \\
\text { ii) Higher Secondary School Certificate examination (public examination) } \\
\text { was postponed until further notice, which was scheduled to begin on April 1, } \\
2020 \text {. }\end{array}$ \\
\hline $\begin{array}{l}\text { March } \\
2020\end{array}$ & $\begin{array}{l}\text { The government ordered to close all government and private offices from } \\
\text { March } 26 \text { until April 4, 2020, to stop the spread of coronavirus. Only } \\
\text { emergency services like law enforcement and healthcare services will be } \\
\text { remain open. }\end{array}$ \\
\hline $\begin{array}{l}\text { March 24, } \\
2020\end{array}$ & $\begin{array}{l}\text { i) The government declared a 10-day ban on all public transport including } \\
\text { water, rail, and domestic air service from March } 26 \text { till April 4, 2020, and it } \\
\text { is now continuing. } \\
\text { ii) The government deployed the armed forces, including police and army, to } \\
\text { ensure that people maintain social distancing and quarantine to prevent } \\
\text { spread of the deadly COVID-19. } \\
\text { iii) Civil Aviation authority of Bangladesh suspended all domestic flights } \\
\text { until April } 4,2020 \text {. }\end{array}$ \\
\hline $\begin{array}{l}\text { March } \\
2020\end{array}$ & $\begin{array}{l}\text { Civil Aviation authority of Bangladesh suspended all domestic and } \\
\text { international flights from March } 30 \text { till April 7, 2020. }\end{array}$ \\
\hline $\begin{array}{l}\text { March } \\
2020\end{array}$ & $\begin{array}{l}\text { In a nation-wide televised program, the honorable Prime Minister of } \\
\text { Bangladesh arranged a video-conference with top government officials of } \\
\text { Bangladesh and outlined action, measures and plans undertaken by the }\end{array}$ \\
\hline
\end{tabular}




\begin{tabular}{|c|c|}
\hline & $\begin{array}{l}\text { Government against COVID-19. Also, the Prime Minister requested not to } \\
\text { celebrate Bangla New Year on April, } 14 \text {. }\end{array}$ \\
\hline $\begin{array}{l}\text { April } \\
2020\end{array}$ & $\begin{array}{l}\text { Ministry of Public Administration of Bangladesh extended the shutdown until } \\
\text { April, } 9 .\end{array}$ \\
\hline $\begin{array}{l}\text { April } \\
2020\end{array}$ & $\begin{array}{l}\text { i) The Prime Minister of Bangladesh declared a stimulus packages of total } \\
\text { amount of approximately USD } 8.5 \text { billion (about } 2.5 \% \text { of GDP) to tackle the } \\
\text { effects of the COVID-19 on the economy of the country. } \\
\text { ii) The government again extended the shutdown including three general } \\
\text { holidays until April 14, } 2020 \text {. } \\
\text { iii) Civil Aviation authority of Bangladesh announced the extension of } \\
\text { suspention of all domestic and international flights until April } 14,2020 \text {. }\end{array}$ \\
\hline $\begin{array}{l}\text { April } \\
2020\end{array}$ & $\begin{array}{l}\text { Civil Aviation authority of Bangladesh further extended the suspention of all } \\
\text { domestic and international flights from until April 30,2020. }\end{array}$ \\
\hline $\begin{array}{ll}\text { April 12, } \\
2020\end{array}$ & $\begin{array}{l}\text { The government of Bangladesh declared a new stimulus packages of total } \\
\text { amount of approximately USD } 589 \text { million for agricultural sector. }\end{array}$ \\
\hline \multicolumn{2}{|c|}{$\begin{array}{l}\text { The financial packages announced by the Prime Minister of Bangladesh to tackle the } \\
\text { socio-economic losses caused by the lethal COVID-19 }\end{array}$} \\
\hline Package-1 & $\begin{array}{l}\text { i) To provide working capital facilities for the affected industries and service } \\
\text { sector organizations, a loan facility of approximately USD } 3,529 \text { million } \\
\text { created to provide working capital in the short term through the bank system. } \\
\text { ii) On the basis of bank-client relationship, the working capital loan is to be } \\
\text { given to the respective industries/businesses organization by the commercial } \\
\text { banks from their own funds. The interest rate of this loan will be } 9 \% \text {. Half of } \\
\text { the interest on the loan is paid by the borrower and the rest of the half will be } \\
\text { paid by government. }\end{array}$ \\
\hline Package-2 & $\begin{array}{l}\text { i) Providing Working Capital Benefits to Small (Cottage Industries) and } \\
\text { Medium Enterprises: A loan facility of approximately USD 2,353 million } \\
\text { will be created to provide working capital in the short term through the bank } \\
\text { system. }\end{array}$ \\
\hline
\end{tabular}




\begin{tabular}{|c|c|}
\hline & $\begin{array}{l}\text { ii) On the basis of bank-client relations, commercial banks will lend the } \\
\text { working capital to concerned small and medium enterprises with their own } \\
\text { funds. The interest rate of this loan will also be } 9 \% .4 \% \text { loan will be paid by } \\
\text { small and medium enterprises and the remaining } 5 \% \text { will be paid by the } \\
\text { government to the concerned bank. }\end{array}$ \\
\hline Package-3 & $\begin{array}{l}\text { i) Extending the Benefits of Export Development Fund (EDF) initiated } \\
\text { Bangladesh Bank: Under the Block to Block LC, the current size of the EDF } \\
\text { will be increased from USD } 3.5 \text { billion to USD } 5 \text { billion to increase the } \\
\text { import of raw materials. } \\
\text { ii) As a result, an additional approximately USD } 1,500 \text { million will be added } \\
\text { to the EDF fund, equivalent to USD } 1.5 \text { billion. The current interest rate for } \\
\text { the EDF will be reduced from LIBOR (The London Inter-Bank Offered } \\
\text { Rate) }+1.5 \% \text { (which is actually } 2.73 \% \text { ) to } 2 \% \text {. }\end{array}$ \\
\hline Package-4 & $\begin{array}{l}\text { Bangladesh Bank will launch a new loan facility of approximately USD } 589 \\
\text { million named Pre-shipment Credit Refinance Scheme. The interest rate of } \\
\text { this loan will be } 7 \% \text {. }\end{array}$ \\
\hline Package-5 & $\begin{array}{l}\text { The Prime Minister has already announced an emergency incentive package } \\
\text { of approximately USD } 589 \text { million to pay the salaries / allowances of } \\
\text { workers and employees of export oriented industries. }\end{array}$ \\
\hline \multirow[t]{2}{*}{$\begin{array}{l}\text { For } \\
\text { Agricultural } \\
\text { Sector }\end{array}$} & $\begin{array}{l}\text { i) The government of Bangladesh has announced a new stimulus package of } \\
\text { approximately USD } 589 \text { million to provide financial support to the farmers } \\
\text { in rural areas for boosting agricultural production facing the fallout of } \\
\text { COVID-19. This package titled 'Special Incentive Re-financing Scheme for } \\
\text { Agriculture Sector' is allocated for ensuring smooth flow of capital for non- } \\
\text { crop agriculture sub-sectors dependent on working capital, including } \\
\text { seasonal fruit and flower cultivation, fisheries, poultry, dairy and livestock. }\end{array}$ \\
\hline & $\begin{array}{l}\text { ii) To meet the country's food demand, different initiatives, including } \\
\text { stimulus packages and approximately USD } 1060 \text { million has been allocated } \\
\text { for boosting crop production amid the CoV outbreak. } \\
\text { iii) Approximately USD } 15 \text { million for rehabilitation of farmers, while } \\
\text { approximately USD } 6 \text { million for the farmers affected by natural disasters }\end{array}$ \\
\hline
\end{tabular}


and cooperatives agriculture, and approximately USD 9 million for expansion of new crops and agriculture technology have been allocated.

iv) For distributing machineries and seeds among farmers as agriculture assistance approximately USD 23.5 million has been allocated. Approximately USD 4.1 million has been allocated for buying Aus seeds and fertilizers, while approximately USD 4.25 million for irrigation.

v) To mitigate the possible shortage of laborers during the harvesting period of boro crop amid $\mathrm{CoV}$ outbreak, 180 combined harvesters and 137 reapers has been allocated for the farmers of the haor regions on emergency basis.

vi) The government has allocated additional approximately USD 12 million for mechanization of agriculture sector.

vii) Nearly 800 combined harvesters and 400 reapers from this amount will be distributed among farmers soon. 


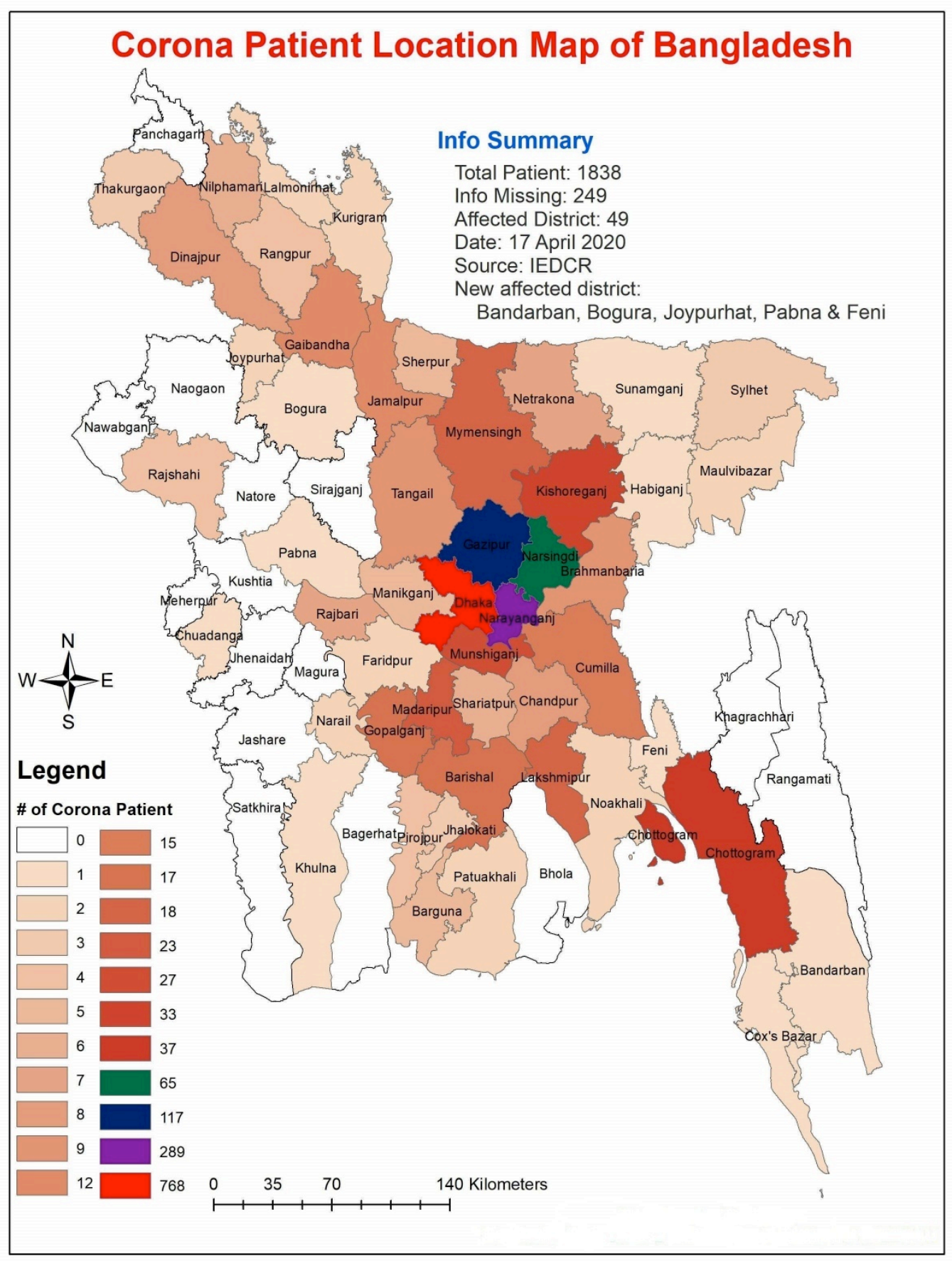

Figure 1. COVID-19 infected patient's location map of Bangladesh. It shows community transmission is occurring in Bangladesh. People from 49 districts have already been infected with COVID-19. 